\title{
FROM BALLAST WATER TO HARMFUL AIR EMISSIONS: HOW TO REDUCE THE IMPACT OF SHIPPING ON THE POLLUTION OF THE MARINE ENVIRONMENT - A REVIEW
}

\author{
MAJA ČOVIĆ, BRUNA BACALJA, MAJA KRČUM \& GORANA JELIĆ MRČELIĆ \\ University of Split, Faculty of Maritime Studies, Croatia
}

\begin{abstract}
Due to increasing concerns regarding the adverse effects of the maritime industry on the marine environment, there is a growing number of environmental studies. This paper aims to provide an overview of marine pollution caused by shipping, which includes different pollutants from harmful air emissions to noise pollution, potential threats to environmentally sensitive or protected areas and to the whole marine environment. Descriptive research method is used to determine challenges on environmental pollution subject, with aim to contribute to the minimization of pollution. Paper presents how, while in recent years social responsibility awareness has grown stronger among shipping companies and while states have developed and implemented strategies and regulatory reforms that establish principles to prevent pollution, there is much space left for improvement. Technologies must further be researched, as there are long-term benefits of further pollution reduction.

Keywords: shipping, marine environment, pollution, MARPOL, ports.
\end{abstract}

\section{INTRODUCTION}

Marine pollution is defined as direct or indirect human impact on the marine environment which has adverse effects on living resources, human health, marine activities, and quality of seawater.

The pollution ending up in the seas and oceans originates from four different sources, as shown in Fig. 1. Those sources include pollution from the land (44\%), pollution through the atmosphere (33\%), pollution due to maritime activity (12\%), garbage and sewage dumping and consequences of offshore drilling and mining which are responsible for the rest (resp. $10 \%$ and $1 \%$ ) (Fig. 1) [1]. Some shipping and port activities have a greater potential impact on the marine environment and those include:

- $\quad$ oil spills;

- hazardous materials spills;

- disposal of waste materials (marine debris) and sewage;

- air emissions;

- ballast water discharge;

- usage of antifouling paints;

- dredging and the disposal of dredged waste;

- physical damage of marine habitats;

- light pollution; and

- noise emissions.

The potential impacts are usually greater for inshore waters and around port areas due to the low water exchange rate. In port areas are gathered direct sources of marine pollution input. A large number of ships represent potential threats in marine pollution [1]. 


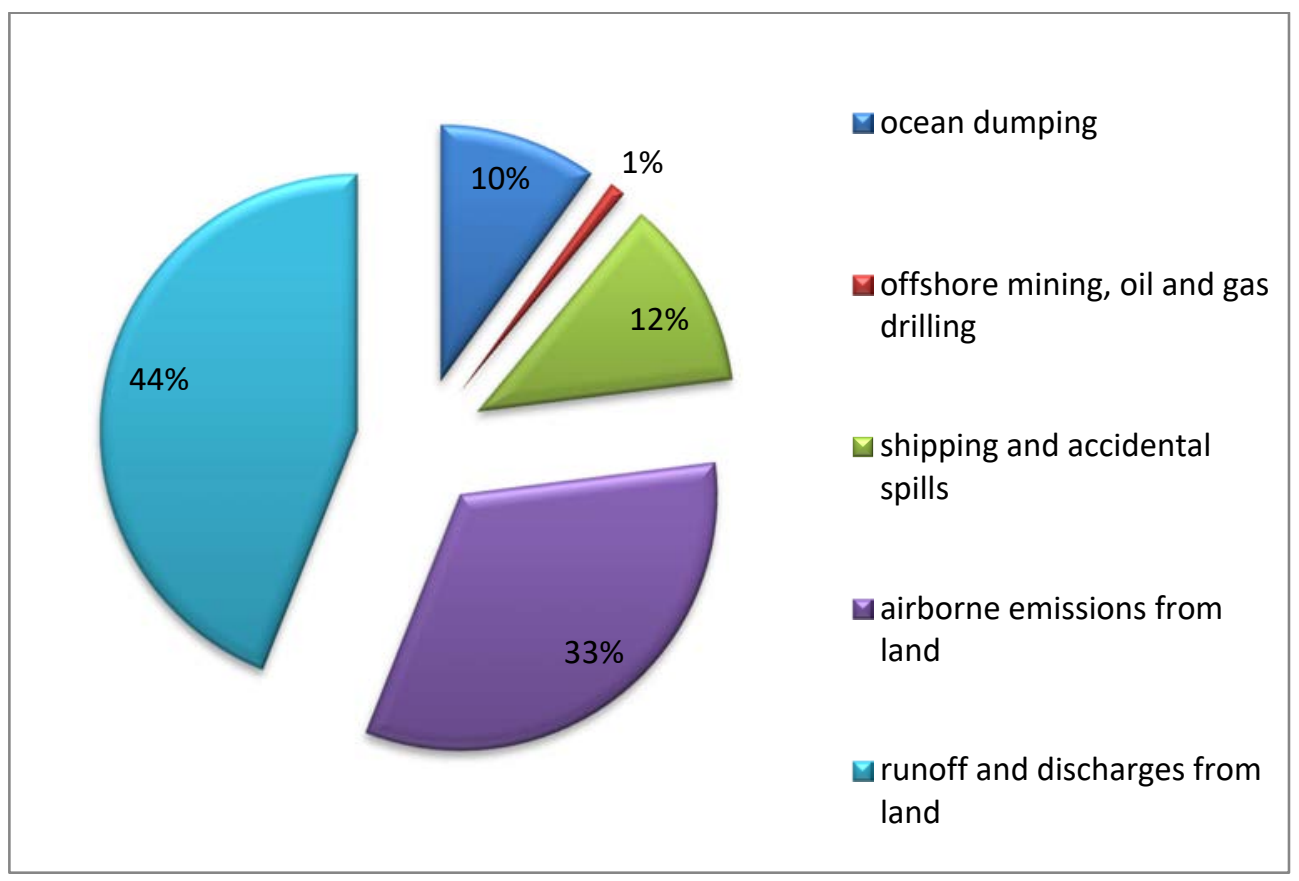

Figure 1: Share of the different sources of pollution into the marine environment. (Source: After IMO 2012.)

\section{OIL AND CHEMICAL SPILLS POLLUTION}

Oil pollution occurs from shipping activity and offshore oil production. Although the impact of the oil and chemical spills pollution doesn't contribute to overall ocean pollution as much as pollution from the land or pollution through the atmosphere, the consequences are extremely disruptive for oceans landscape and inhabitants [2].

Ports conduct intense cargo-handling activities with the potential to contaminate water, soil, and sediments through accidental spills and maintenance operations (e.g. leaking fuel, lubricant, cleaning agent, liquid or dry bulk cargo) [3].

When the oil spills into the sea, it spreads quickly over the surface. Pollution range depends on the relative density and composition of the oil. Therefore, the prevention of oil spillage from ships is the first step in keeping the sea unpolluted.

International Convention for the Prevention of Pollution from Ships (MARPOL) has a major role in regulating shipping pollution. The MARPOL Annex 1, which entered force on 2nd October 1983, aims to protect the marine environment by lowering the possibilities of accidental discharges and through the elimination of pollution by oil and other damaging elements [4].

MARPOL Annex 1 covers all the fluids which contain oil; equipment condition and maintenance, controls oil discharges in general and in special areas and proposes surveys and certificates. 


\section{SEWAGE POLLUTION}

Even though the primary sources of human-produced sewage are land-based, shipping sewage discharges are also contributing to marine pollution. The ships produce two types of wastewater referred to as black and grey water.

Black water is toilet waste sewage, and grey water is cooking and cleaning waste. Even though black water has higher pollutant concentration in most treatment systems used in passenger ships, black and graywater are collected in the same tank and treated through the same treatment processes [5].

Sewage can lead to health hazards and oxygen depletion. A large cruise ship with 3,000 passengers generates over more than 100,000 liter of human waste a day [5]. Discharges of the merchant ships have the $40-50 \%$ of the total deleterious impacts on the environment [6]. Reviewing the literature, several studies are found written on liquid waste from ships.

The study by Westhof is based on the determination of the types and the concentration of different pollutants in the ship wastewater [7]. The samples are taken from 4 cruise ships during calls in Hamburg, Germany. 16 out of 21 targeted micro-pollutants were detected in both the black water and grey water on board, emitted from either the passengers or certain ship operations.

According to the theoretical calculation, annually generated food waste on board ships in traffic in the Baltic Sea contains about 182 tonnes of nitrogen and 34 tonnes of phosphorus. The annual load of nitrogen in the food waste corresponds to $52 \%$ of the load of nitrogen from the sewage [8].

Regulations for the prevention of pollution by sewage are contained in MARPOL Annex IV. MARPOL Annex IV regulates prevention and supervision of marine pollution by sewage waste waters from ships. Annex IV refers to prohibiting or limiting discharge, issuance of certificates and inspections, equipment and discharge supervision, shore reception facilities. if the ship has one of sewage treatment systems, sewage can be discharged at 3 nautical miles $(\mathrm{nm})$ from the coast. If a ship is not equipped with any treatment system, sewage has to be discharged at $12 \mathrm{~nm}$ from the coast. Additional requirements apply to special areas, which are currently only the Baltic Sea area [4].

\section{SOLID WASTE POLLUTION}

Ships produce solid waste (e.g., organic, domestic and operational waste) that must be properly treated to reduce health risks for crew and their environmental footprint [2]. Garbage generated from ships is a significant source of coastal pollution due to the illegal disposal into the sea and the lack of proper handling onshore [9].

Waste and sewage discharges are of greatest concern in coastal regions and semiprotected bodies of water. International legislation such as MARPOL Annex V prevents pollution of waste by ships [4]. Since January 1, 2013, the international MARPOL convention prohibits discharging of any garbage (except food waste and non-harmful cargo residues in small quantities) at sea.

MARPOL 73/78 places an obligation on parties to ensure that ports provide waste reception facilities to dispose of ships waste. Litter disposal and accumulation in the marine environment is one of the fastest-growing threats to the health of the world's oceans [10]. Marine litter is defined as any persistent, manufactured, or processed solid material discarded, disposed or abandoned in the marine and coastal environment.

Marine debris can be classified into several distinct categories:

- Plastics,

- Metal, 
- Glass,

- Processed timber,

- Paper and cardboard,

- Rubber, and

- Clothing and textiles [11].

Most of the marine debris has a very low decomposition rate. The waste material can take up to 450 years to be degraded and is the main destroyer of the life in the ocean [1]. Approximately $80 \%$ of marine debris originates from land-based sources [12]. The estimation from 24 expeditions in the period between 2007 and 2013 concluded that 5.25 trillion plastic particles of different sizes were floating at sea [13]. In 2010, between 4.8 and 12.7 million metric tons out of 275 million metric tons of plastic from 192 coastal countries entered the ocean [14]. According to the study based on Greece coastal areas, marine debris density was 15 items per $1,000 \mathrm{~m}^{2}$ with plastics dominating [15].

Marine debris affects marine life. Individual species may become threatened or suffocated by marine debris, or it can be mistaken for food. It supports the growth and transport of microbes to new habitats. Dinoflagellates, including those responsible for harmful algal blooms, are found growing on plastic debris. This raises the possibility of increment of harmful algal blooms together with the increment of marine debris [16].

Due to the above-mentioned impacts of marine debris, the first step of debris reduction is the prevention of its releasing into the environment. Existing marine debris can be removed before it enters the sea, through litter collection and screening wastewater systems or by marine debris collection from coast and sea.

Fig. 2 shows simulation of evolution of drifter density (or marine debris) from an initally homogeneous state, and after 10 years of advecation by currents, as determinated from real drifter movements.

\section{AIR EMISSIONS POLLUTION}

Shipping generates air emissions via fossil fuels combustion. By transfering transboundary in atmosphere, air polluton affects air quality globally. Ship engines produce carbon dioxide $\mathrm{CO}_{2}, \mathrm{SO}_{2}$ and $\mathrm{NO}_{2}$, which contribute to acid rain formation and global warming. Carbon dioxide $\left(\mathrm{CO}_{2}\right)$ is the most significant contributor to the greenhouse effect.

Shipping is responsible for approximately 940 million tons of $\mathrm{CO}_{2}$ annually [17]. As reported by several authors, shipping contributes to the overall anthropogenic emission of $\mathrm{CO}_{2} 3.1 \%$, SOx from 5 to $8 \%$ and NOx by $15 \%$ [18], [19]. Above mentioned greenhouse gases (GHGs) and pollutants cause health risks and can have a significant effect on the air quality. Air quality of coastal areas is affected by shipping since $70 \%$ of the ship emissions are occurring within $400 \mathrm{~km}$ of land [18].

Shipping-related emissions depend on several factors such as fuel type (RO - Residual Oil (heavy fuel oil), MDO - Marine Diesel Oil and MGO - Marine Gas Oil) and engine type (slow speed diesel, medium-speed diesel, high-speed diesel, gas turbine and steam turbine).

The IMO is through MARPOL Annex VI limiting the main air pollutants connected to shipping, including sulfur oxides (SOx) and nitrous oxides (NOx) [4]. The percentage of sulfur used in marine fossil fuels is lowering from year to year. The sulfur content of any fuel used on board shall not exceed $0.50 \%$ by weight from 1 January 2020 onwards, with even stricter limits in emission control areas (ECAS). Ships berthed in ports must use fuel with sulfur content less than 0.1 by weight [20]. NOx emissions are regulated by the Different levels (Tiers) of control, which differ based on the ship construction date and engine speed. 

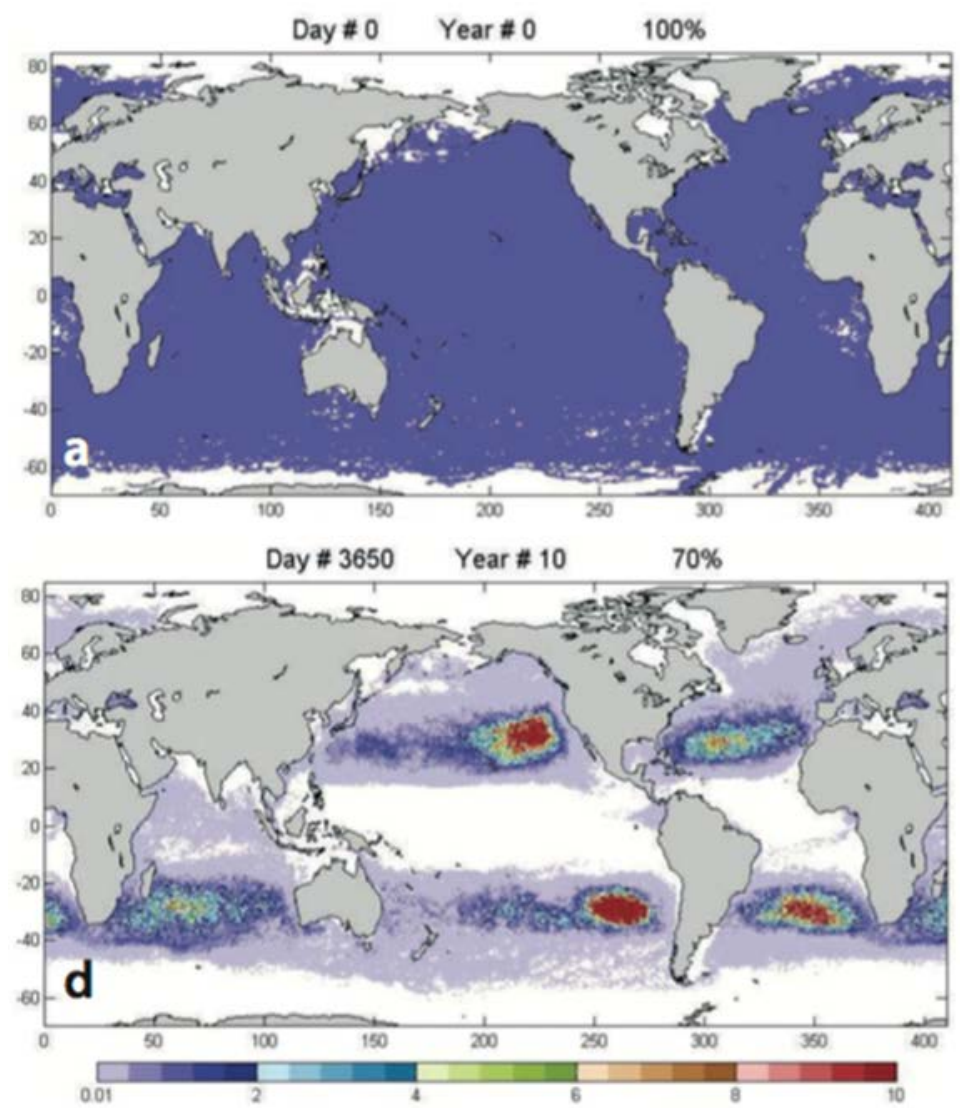

Figure 2: Simulation of evolution of drifrer density (or marine debris): (a) from an initally homogeneous state, (2) after 10 years of advecation by currents, as determinated from real drifter movements. Units represent relative change in drifter concenreation. (Source: Image taken from IPRC Climate, vol. 8, no. 2, 2008.)

Figs 3 and 4 show the ozone change and the contribution from shipping emissions to air quality.

\section{BALLAST WATER POLLUTION}

Ballast water is now one of the most significant pollutants, and is associated with aporoximately $1 / 3$ of documented invasions globally. One of the greatest challenges for maritime shipping is to find safe ballast water management solutions, while minimizing system impacts on environment.

Marine transportation continues to grow, with $\sim 51,400$ merchant ships trading globally, and $\sim 3-5$ billion tons of ballast water transferred by ships annually. This produces an increased risk of the introduction of invasive aquatic species following discharge of untreated ships' ballast water, representing a significant threat to global biodiversity. The establishment of exotic species can cause the alteration of the entire ecosystems and habitat and the extinction of indigenous species by predation of competition (ANZECC). 

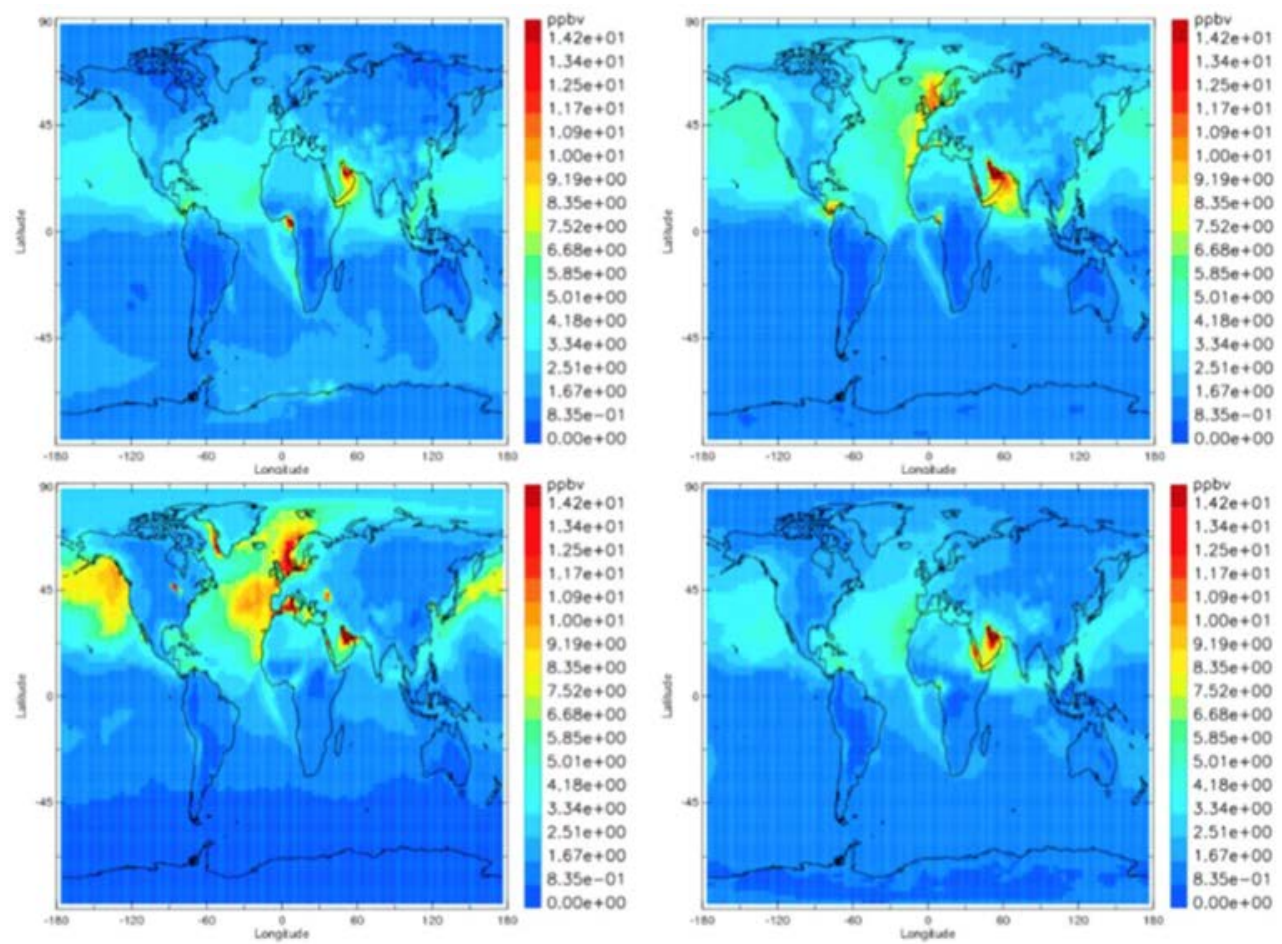

Figure 3: Ozone change at the surface due to year 2000 ship emissions simulated by the OsloCTM2 for the months (top left) January, (top right) April, (bottom left) July and (bottom right) October [18]. (Source: Dalsøren et al., 2007, their Fig. 5; Copyright, 2007; American Geophysical Union; Reproduced by permission of American Geophysical Union.)

Most primary and secondary invasions of AIS occur via ballast water exchange at port, with ships traveling and dispersing their ballast internationally, nationally, and locally. The probability of organisms surviving ballast water exchange depends on the origin of water and where it is discharged. Table 1 shows the probability of organism survival and reproduction in freshwater, brackish water, and saline water. Even after few weeks, after ballast water is taken up, there is a chance algae and larval forms, or other organisms which came from thousands of kilometers away, can survive. Table 1 also shows the probability of organism survival and reproduction in freshwater $(\mathrm{FW})$, brackish water $(\mathrm{BW})$ and saline water $(\mathrm{SW})$ [22].

\section{ANTIFOULING COATINGS POLLUTION}

Antifouling paints are designed to protect the vessel's hull and slow the growth of aquatic organisms. Antifouling paints may contain toxic substances such as cuprous oxide, mercuric oxide, and tributyltin (TBT) which can harm the environment.

The paints gets removed slowly by the ship movement in the sea water. This brings new toxin layer on the surface and prevents growth of marine organisms. The effects of 


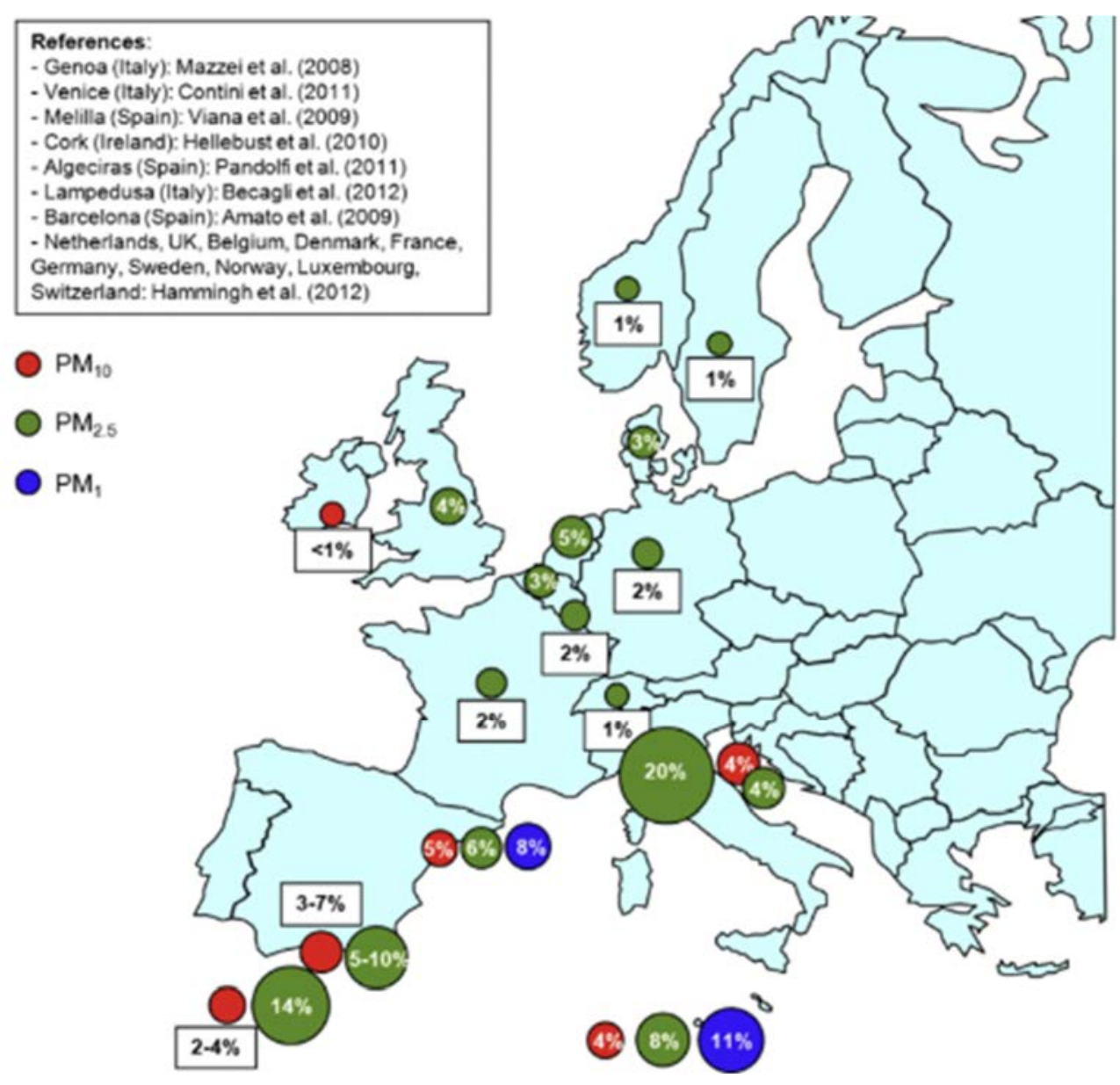

Figure 4: Contribution from shipping emissions to air quality $\left(\mathrm{PM}_{10}, \mathrm{PM}_{2.5}\right.$, and $\left.\mathrm{PM}_{1}\right)$ across Europe [21].

Table 1: Probability of organism survival and reproduction in freshwater (FW), brackish water (BW), and fully saline water (SW). (Source: Adapted from IMO, 1991.)

\begin{tabular}{|c|c|c|c|}
\hline \multirow{2}{*}{ Receiving waters } & \multicolumn{3}{|c|}{ Discharged ballast } \\
\cline { 2 - 4 } & FW & BW & SW \\
\hline FW & High & Medium & Low \\
\hline BW & Medium & High & High \\
\hline SW & Low & High & High \\
\hline
\end{tabular}

antifouling compounds are of most concern in semi-enclosed bodies of water such as bays and estuaries with a high density of boats. Organisms which attach themselves to the ship hull during biofouling include calcareous fouling organisms [23]. 


\section{POLLUTION CAUSED BY DREDGING}

Dredging is activity carried out in order to remove unwanted deposits from marine water pathways. Removing unwanted seabed deposits to different location can affect the ecosystem, particularly in closed areas. Usually dredging is part of regular port operations and maintainance.

Dregging threatens marine environment by changing the sol compoistion. These changes impact existing habitats of such area. Dredging of soils wich are contaminated may cause their spreadability to a larger areas in the water body. Also, mixtures of contamined soil with water can affect pollution. Among studies about dredging unwanted imact on seagrass, there are several recent cases that reported no impacts on seagrass [24].

\section{NOISE EMISSIONS}

Water is an efficient medium for transporting sound waves. In the marine environment, sound transmission is highly variable and can be dependant on the acoustic properties of the seabed and surface, variations in sound speed, and the temperature and salinity of the water [25].

Noise pollution is growing, with anthropogenic sound coming from cargo ships, sonar systems, seismic testing, drilling, pile drivers etc., which causes concerns regarding marine organisms. Noise pollution can cause stress in animals and increase the risk of mortality [26].

\section{POLLUTION IN PORTS}

Historically, ports and shipping companies have operated with little regard for environmental impacts, while legislation aimed at protecting the environment associated with the operation and management of port facilities and marine transportation companies are now well established. For example, the 1998 ECOPORTS project (Towards a Sustainable Transport Network), was developed by the Valencia Port Authority (VPA), to establish an Environmental Management System (EMS) in industrial harbors (ECOPORTS Valencia, 2000). Many ports have already adopted environmental performance indicator (PI) frameworks such as ECOPORTS, Port Environmental Review System (PERS), INDAPORT and PORTOPIA aimed towards sustainable port management [27]. Port authorities also try to meet social and environmental obligations whilst embedding environmental and corporate social responsibility (CSR) concepts in port management systems. There is a lot of competition among the ports to improvement require regional agreements, with aim to further prevent pollution. To establish additional support, in 1993, European Sea Ports Organisation (ESPO) was created, with a mission to influence public policy in the European Union to achieve a safe, efficient and environmentally sustainable European port sector. The ESPO goals provide excellence in port environmental management and sustainability and introduce a framework for port authorities [28]. Ports in Europe have made significant progress in addressing pollution from shipping. According to the European Sea Ports Organisation's (ESPO) Environmental Report for 2020 one third of European ports have made LNG bunkering services available and $34 \%$ of these ports can provide ship-to-ship LNG bunkering. The same report noted that $58 \%$ of sampled ports in 2020 are providing shoreside electricity for ships at berth and $46 \%$ of these ports provide high voltage electricity suitable for seagoing vessels. Two-thirds of European ports are certified with environmental standards, which is increment by $11 \%$ since 2013 and $81 \%$ of ports have set up an environmental monitoring program. 


\section{LEGAL FRAMEWORK}

In order to prevent pollution and raise awareness, International Conventions were implemented among states. Enforcement of conventions depends upon the Governments of Member Parties, and some of implemented Conventions are:

- The United Nations Convention on the Law of the Sea (UNCLOS). Convention is created due to the increasing threat of pollution, with aim to protect and preserve marine environment.

- The International Convention for the Safety of Life at Sea (SOLAS) was adopted as part of the IMO, with objective to establish the minimum safety standards for the construction, equipment and operation of ships.

- The International Convention for the Prevention of Pollution from Ships (MARPOL), with aim to eliminate intentional or accidental pollution of the marine environment from ship.

- The International Convention on Standards of Training, Certification and Watchkeeping for Seafarers (STCW), that prescribes the basic requirements for training, certification and watchkeeping for seafarers.

- The International Convention relating to Intervention on the High Seas in Cases of Oil Pollution Casualties, which was aimed at preventing, minimiseing, or eliminating the threat for the coast caused by a marine incident.

- The Convention on the Prevention of Marine Pollution by Dumping of Wastes and Other Matter, which prohibits the dumping of certain hazardous substances.

- The International Convention on Oil Preparedness, Response and Cooperation (OPRC) which requires establishment of measures for pollution incidents.

- The International Convention for the Control and Management of Ships' Ballast Water and Sediments (BWC), implemented to prevent, minimise and eliminate the transfer of dangerous aquatic organisms and pathogens.

- The International Convention on the Control of Harmful Anti-fouling Systems on Ships (AFS Convention). Parties to the Convention are required to prohibit and/or restrict the use of harmful anti-fouling systems on ships flying their flag, as well as ships not entitled to fly their flag but which operate under their authority and all ships that enter a port, shipyard or offshore terminal of a Party. Anti-fouling systems to be prohibited or controlled.

- The Hong Kong International Convention for the Safe and Environmentally Sound Recycling of Ships. The Convention covers: the design, construction, operation and preparation of ships in order to facilitate safe and environmentally sound recycling [29].

\section{CONCLUSIONS}

At the moment, there is a global discussion to find solutions and take action for reducing and preventing marine pollution. Current knowledge on how pollution occurs is of a major importance and should be used as a first step in minimizing pollution occurrence. Joint work of government, industry and non-governmental organizations on preventing pollution has a more positive effect on human health and the environment.

For oil and chemical spills, prevention is the best solution. Any operation involving the handling of oil or fuel should be accomplished in a way that minimizes the possibility of accidental release such as not overfilling fuel tanks to reduce the chance of spills, recycle used oil and filters and deliver used oil to a collection site. Oil management is done via 
ODME (oil discharge monitoring equipment) in tankers or OWS (oily water separator) on all ships.

Ships discharge ballast water, bilge water, grey water, and black water into the sea which has a negative impact on the environment and human health. Effective sewage treatments are good prevention for black water discharge.

As stated before, $80 \%$ of marine litter is land-based. Reduction of marine litter should start with the reduction of land-based litter which ends in the marine environment. It should be followed by reducing the amount of sea-based sources of marine debris.

The regulations to prevent air pollution include limitation of emissions, installation of exhaust gas cleaning systems, limitation of sulfur content in fuel and replacing fossil fuels with alternative energies like solar and wind.

Ballast water treatment methods include mechanical treatments (filtration and separation) physical treatments (heat or ultraviolet), and chemical treatments. Mechanical treatments separate marine organisms from the ballast water using filtration systems. Ultraviolet rays affect the DNA of the organisms making them harmless. Chemical treatments such as biocides inactivate marine organisms in the ballast water, but can potentially harm other marine organisms. Organizations are implementing new technologies to prevent further pollution caused by ballast water and to prevent invasive species import.

Antifouling paints based on biocide should be replaced with adopt non-toxic alternatives, to minimize pollution and harm caused by paints on the environment.

There is a wide range of possibilities for prevention and reduction of pollution in ports such as replacement of old - more polluting vessels, re-powering existing vessels, usage of low-sulfur diesel fuel, shore power for ships at berth, alternative fuels and emission control systems, waste management.

EU Directive 2000/59/EC requires that European Union ports provide reception facilities for the waste generated by ships. This directive covers all sea-going vessels and all EU ports. Directive emphasizes the availability and the capacity of reception facilities, waste reception and handling plans, delivery of waste and costs (fees).

Port authorities can financially simulate ship-owners to invest in new vessels or re-power existing vessels that use lower emitting engines or renewable energy sources to contribute to pollution reduction. During the hotelling phase when vessels are at berth, diesel auxiliary engines used for power are contributing to the pollution.

Port authorities should enable shore power connection and require ships to plug into shore-side power connection while at berth to reduce air pollution. Ships should use lowsulfur diesel fuel while in coastal waters and at berth.

Air quality monitoring should ensure acceptable levels of emissions at the port area. Ports can have one or more control zones. Limitations should be in accordance with the regional environmental management plan.

The more polluting ships should pay higher fees when entering port. A similar program is already implemented in Sweden.

Port authorities should ensure sufficient port waste management for receiving all types of ship discharges including liquid and solid waste according to the MARPOL provisions. Long-term prevention is focusing on the local production of goods to reduce marine traffic in ports.

With the rise of pollution threats, caused by the constant rise of traffic and tech development, it is essential to do further research and develop models which would further help to reduce pollution. 


\section{REFERENCES}

[1] Potters, G., Marine Pollution, 1st edn, 2013.

[2] Walker, T.R., Green Marine: An environmental program to establish sustainability in marine transportation. Mar. Pollut. Bull., 2016.

DOI: 10.1016/j.marpolbul.2016.02.029.

[3] Asariotis, R. et al., Review of Maritime Transport 2018, 2018.

[4] Convention, M., International convention for the prevention of pollution from ships. MARPOL Conv. Outl., 1973.

[5] Şahin, V.\& Vardar, N., Determination of wastewater behavior of large passenger ships based on their main parameters in the pre-design stage. J. Mar. Sci. Eng., 8(8), pp. 118, 2020. DOI: 10.3390/JMSE8080546.

[6] Gibson, M., Murphy, A.J. \& Pazouki, K., Evaluation of environmental performance indices for ships. Transp. Res. Part D Transp. Environ., 2019.

DOI: $10.1016 /$ j.trd.2019.07.002.

[7] Westhof, L., Köster, S. \& Reich, M., Occurrence of micropollutants in the wastewater streams of cruise ships. Emerg. Contam., 2016. DOI: 10.1016/j.emcon.2016.10.001.

[8] Wilewska-Bien, M., Granhag, L. \& Andersson, K., The nutrient load from food waste generated onboard ships in the Baltic Sea. Mar. Pollut. Bull., 2016.

DOI: 10.1016/j.marpolbul.2016.03.002.

[9] To, N.T. \& Kato, T., Solid waste generated from ships: A case study on ship-waste composition and garbage delivery attitudes at Haiphong ports, Vietnam. J. Mater. Cycles Waste Manag., 19(2), pp. 988-998, 2017. DOI: 10.1007/s10163-016-0466-3.

[10] Pham, C.K. et al., Marine litter distribution and density in European seas, from the shelves to deep basins. PLoS One, 2014. DOI: 10.1371/journal.pone.0095839.

[11] Wang, J. et al., Chapter 25. Marine Debris. 2016.

[12] Allsopp, M., Walters, A., Santillo, D. \& Johnston, P., Plastic debris in the world's oceans. World, 2006.

[13] Eriksen, M. et al., Plastic pollution in the world's oceans: More than 5 trillion plastic pieces weighing over 250,000 tons afloat at sea. PLoS One, 2014. DOI: 10.1371/journal.pone.0111913.

[14] Jambeck, J.R. et al., Marine pollution. Plastic waste inputs from land into the ocean. Science, 2015.

[15] Katsanevakis S. \& Katsarou, A., Influences on the distribution of marine debris on the seafloor of shallow coastal areas in Greece (eastern Mediterranean). Water. Air. Soil Pollut., 159(1), pp. 325-337, 2004. DOI: 10.1023/B:WATE.0000049183.17150.df.

[16] Masó, M., Garcés, E., Pagès, F. \& Camp, J., Drifting plastic debris as a potential vector for dispersing Harmful Algal Bloom (HAB) species. Sci. Mar., 2003.

DOI: $10.3989 /$ scimar.2003.67n1107.

[17] Smith, T.W.P. et al., Third IMO greenhouse gas study 2014. Int. Marit. Organ., p. 327, 2014. DOI: $10.1007 / \mathrm{s} 10584-013-0912-3$.

[18] Eyring, V. et al., Transport impacts on atmosphere and climate: Shipping. Atmos. Environ., 44(37), pp. 4735-4771, 2010. DOI: 10.1016/j.atmosenv.2009.04.059.

[19] Shipping and climate change | Transport \& Environment. https://www.transportenvironment.org/what-we-do/shipping-and-environment/ shipping-and-climate-change. Accessed on: 7 Feb. 2021.

[20] Merico, E. et al., Atmospheric impact of ship traffic in four Adriatic-Ionian port-cities: Comparison and harmonization of different approaches. Transp. Res. Part D Transp. Environ., 2017. DOI: 10.1016/j.trd.2016.11.016. 
[21] Viana, M. et al., Impact of maritime transport emissions on coastal air quality in Europe. Atmospheric Environment, 2014. DOI: 10.1016/j.atmosenv.2014.03.046.

[22] Scriven, D.R., DiBacco, C. Locke, A. \& Therriault, T.W., Ballast water management in Canada: A historical perspective and implications for the future. Marine Policy, 59, 2015.

[23] Sheppard, C.R.C., World Seas: An Environmental Evaluation: Volume III: Ecological Issues and Environmental Impacts, Academic Press (an imprint of Elsevier), pp. 516517, 2018.

[24] Clark, R.B., Marine Pollution, 5th edn, Oxford University Press, 2002.

[25] O'Brien, J., Chapter II, Impacts of shipping. https://www.environment.gov.au/system/ files/resources/8453a2da-8717-40f8-8ce7-636ae3ec64cf/files/impacts-shipping.pdf. Accessed on: 10 Feb. 2021.

[26] Peng, C., Zhao, X. \& Liu, G., Noise in the sea and its impacts on marine organisms. Int. J. Environ. Res. Public Health, 12, pp. 12304-12323, 2015.

DOI: 10.3390/ijerph121012304.

[27] Walker, T.R., Green marine: An environmental program to establish sustainability in marine transportation. Mar. Pollut. Bull. 105(1), pp. 199-207, 2016.

DOI: 10.1016/J.MARPOLBUL.2016.02.029.ESPUB2016FEB 18.PMID 26899158.

[28] Covic, M. et al., Environmental protection and sustainable ports. 19th International Conference on Transport Science, Portorož, 2020.

[29] Jelić Mrčelić, G., Mandić, N. \& Petrinović, R., International legislative framework. Environmental Impact of Ships (Cambridge Environmental Chemistry Series), eds S. De Mora, T. Fileman \& T. Vance, Cambridge University Press: Cambridge, 2020. DOI: $10.1017 / 9781108381598$. 